\title{
openheart Another typical ST-segment elevation myocardial infarction in the elderly?
}

\author{
Julio Iván Farjat-Pasos, ${ }^{\oplus 1}$ Sergio Alonso Villarreal-Umaña, ${ }^{2}$ Paolo Angelini ${ }^{3}$
}

\section{- Additional material is published online only. To view please visit the journal online (http://dx.doi.org/10.1136/ openhrt-2019-001034)}

To cite: Farjat-Pasos Jl, Villarreal-Umaña SA, Angelini P. Another typical ST-segment elevation myocardial infarction in the elderly?. Open Heart 2019;6:e001034. doi:10.1136/ openhrt-2019-001034

Accepted 14 April 2019

\section{PART 1}

A woman presented to the emergency room complaining resting chest pain, dyspnoea, cold sweating and nausea several hours after symptoms onset. Of note, she had some risk factors for coronary artery disease. She also had been recently notified of a bereavement. On arrival, she was in pain, her vitals were heart rate $90 \mathrm{bpm}$, respiratory rate 20 rpm, blood pressure 90/60 $\mathrm{mm} \mathrm{Hg}$ and $\mathrm{O}_{2}$ saturation $91 \%$. Admission ECG is shown in figure 1 . She was moved emergently to the catheterisation laboratory while being started on $300 \mathrm{mg}$ aspirin, $600 \mathrm{mg}$ clopidogrel, 5000 $\mathrm{U}$ of heparin and $80 \mathrm{mg}$ atorvastatin. Soon, her blood pressure dropped to $60 / 40 \mathrm{~mm} \mathrm{Hg}$ and she was started on vasopressors and intravenous fluid resuscitation achieving a blood pressure of 90/60 $\mathrm{mm} \mathrm{Hg}$. Coronary angiography is shown in figure 1 .

According to your diagnostic suspicion, what would you do next?

a. Aortography from the aortic root. b. Intravascular ultrasound (IVUS) of the left anterior descending (LAD) coronary artery.

c. Left ventriculography.

d. LAD primary angioplasty.

\section{PART 2}

Coronary angiography revealed no evidence of a proximal fixed coronary lesion (figure 1 , bottom) but likely vasospasm of the LAD (figure 1A). In the left anterior oblique (LAO) projection, pericardial effusion was presumed due to the image of a $2 \mathrm{~cm}$ space between the epicardial coronary arteries and the outer border of the heart (figure 1C). Left ventricular end-diastolic pressure pressure was $23 \mathrm{~mm} \mathrm{Hg}$. Finally, left ventriculography was performed (figure 2) and showed hyperkinetic basal segments but anteroapical dyskinesia (figure 2D,E) (takotsubo apical variant). ${ }^{1}$ Contrast media appeared leaking into the pericardial space passing through the apical wall by way of a fistulous
Check for updates

(c) Author(s) (or their employer(s)) 2019. Re-use permitted under CC BY-NC. No commercial re-use. See rights and permissions. Published by BMJ.

${ }^{1}$ Interventional Cardiology, Instituto Nacional de Cardiología Ignacio Chávez, México, Tlalpan, México

Interventional Cardiology, Hospital Star Médica Mérida, Mérida, , México

${ }^{3}$ Interventional Cardiology, Texas Heart Institute, Houston, Texas, USA

Correspondence to Julio Iván Farjat-Pasos; julio. farjat@gmail.com

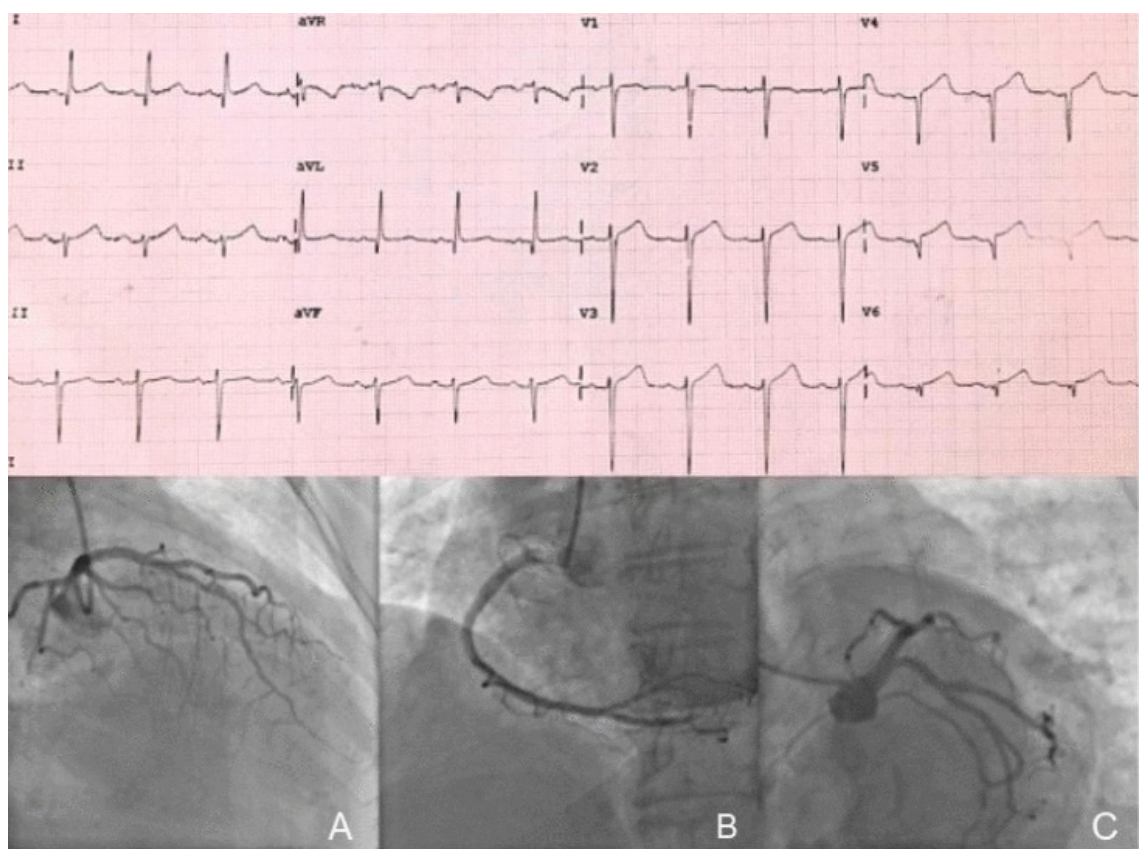

Figure 1 Patient's admission ECG and coronary angiography. 


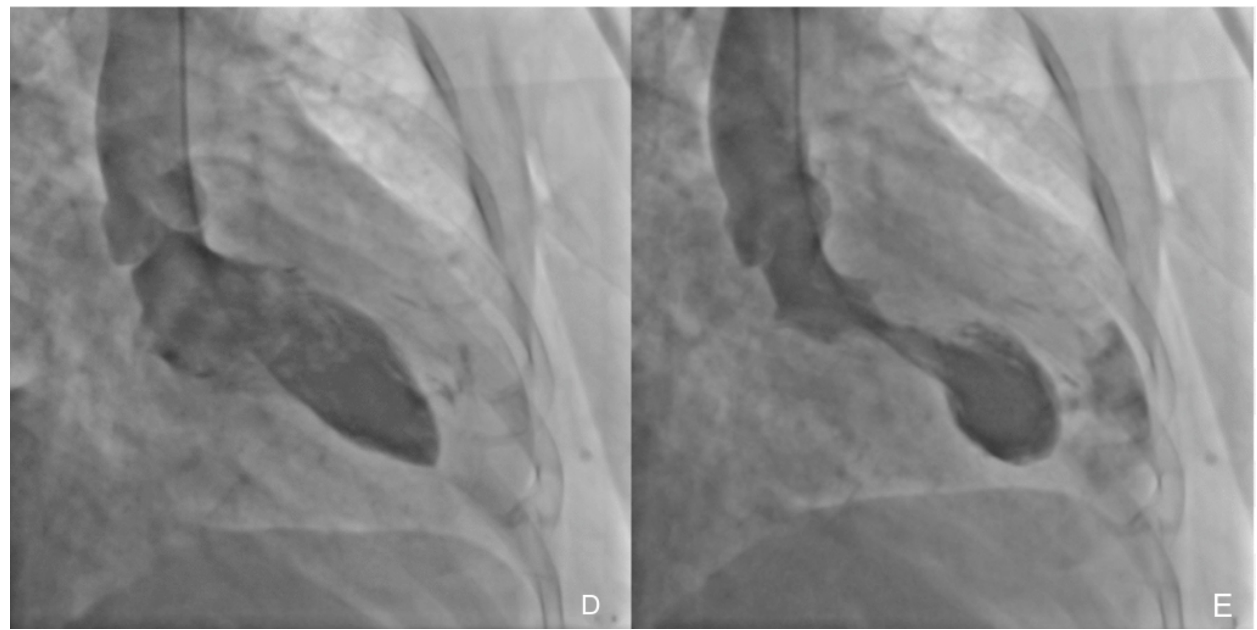

Figure 2 Patient's left ventriculography showing a typical takotsubo's apical ballooning with also a left ventricular free-wall rupture causing the patient's heart tamponade.

tract and collecting outside of it (online supplementary file 1).

The patient's clinical profile, symptoms, mild troponin elevation and ECG findings (aVR ST segment depression, anterolateral ST segment elevation), in the absence of occlusive coronary disease but LAD spasm, suggested the diagnosis of takotsubo cardiomyopathy. ${ }^{2-4}$ The later cardiogenic shock and picture (figure 2) were explained by the apical wall rupture. ${ }^{1}$

An aortography was not indicated because there was no suspicion of aortic pathology. LAD IVUS would have delayed the proper diagnosis in the context of a supposed exclusive LAD spasm. Although coronary spasm and takotsubo cardiomyopathy were once considered separate entities, there is convincing evidence of a common pathophysiology ${ }^{5}$ and there are case reports with this provoked ${ }^{6}$ and spontaneous ${ }^{7}$ association. LAD primary angioplasty was not indicated because there was no evidence of acute coronary thrombosis.

Pericardial effusion puncture with blood autotransfusion was attempted while emergent call to cardiovascular surgery team was being made. The haemodynamic collapse was so abrupt that quickly the patient evolved to cardiac arrest refractory to cardiopulmonary resuscitation manoeuvres. There is a case report in which percutaneous closure of an apical free wall rupture with an Amplatzer occluder was attempted as a bridge therapy to an urgent surgical repair, but the patient finally died after the surgical repair attempt. ${ }^{8}$

Acknowledgements Alejandro Díaz-Cabañas.

Collaborators Alejandro Díaz-Cabañas.
Contributors All the authors have contributed to the planning, conduct and reporting of the work described in the article.

Funding The authors have not declared a specific grant for this research from any funding agency in the public, commercial or not-for-profit sectors.

Competing interests None declared.

Patient consent for publication Not obtained.

Provenance and peer review Not commissioned; externally peer reviewed.

Open access This is an open access article distributed in accordance with the Creative Commons Attribution Non Commercial (CC BY-NC 4.0) license, which permits others to distribute, remix, adapt, build upon this work non-commercially, and license their derivative works on different terms, provided the original work is properly cited, appropriate credit is given, any changes made indicated, and the use is non-commercial. See: http://creativecommons.org/licenses/by-nc/4.0/.

\section{REFERENCES}

1. Pelliccia F, Kaski JC, Crea F, et al. Pathophysiology of takotsubo syndrome. Circulation 2017;135:2426-41.

2. Iskander M, Abugroun A, Shehata K, et al. Takotsubo Cardiomyopathy-Induced cardiac free wall rupture: a case report and review of literature. Cardiol Res 2018;9:244-9.

3. Ghadri J-R, Wittstein IS, Prasad A, et al. International expert consensus document on takotsubo syndrome (Part I): clinical characteristics, diagnostic criteria, and pathophysiology. Eur Heart $J$ 2018;39:2032-46.

4. Ghadri J-R, Wittstein IS, Prasad A, et al. International expert consensus document on takotsubo syndrome (Part II): diagnostic workup, outcome, and management. Eur Heart J 2018;39:2047-62.

5. Madias JE. Pathophysiology of takotsubo syndrome: do not forsake coronary vasospasm! Int J Cardiol 2018;266.

6. Angelini P. Transient left ventricular apical ballooning: a unifying pathophysiologic theory at the edge of Prinzmetal angina. Catheter Cardiovasc Interv 2008;71:342-52.

7. Giusca S, Eisele T, Nunninger P, et al. Aborted sudden cardiac death in a Female patient presenting with Takotsubo-Like cardiomyopathy due to epicardial coronary vasospasm. Case Rep Cardiol 2017;2017:1-4.

8. Elbey MA, Ertas G, Bacaksiz A, et al. Transcatheter closure of left ventricular free wall rupture with Amplatzer atrial septal defect occluder. Clin Res Cardiol 2013;102:313-4. 